\title{
The Relationship Between the Level of Religiosity and Teenage Sexual Behavior in Senior High School
}

\author{
$1^{\text {st }}$ Shanti Ariandini \\ Midwifery Study Program \\ Akademi Kebidanan Prima Husada \\ Bogor \\ Bogor, Indonesia \\ shantiariandini1988@gmail.com
}

\author{
$2^{\text {nd }}$ Annisa Fitri Rahmadini \\ Midwifery Study Program \\ Akademi Kebidanan Prima Husada \\ Bogor \\ Bogor, Indonesia \\ diniensuwasa@gmail.com
}

\begin{abstract}
Based on data from the Family Planning and Coordinating Board (BKKBN) in 2011 showed that $51 \%$ of adolescents in Jakarta, Bogor, Depok, Tangerang, Bekasi (JABODETABEK) have had sex before marriage. According to Handayani (2010) there is a significant relationship between the level of adolescent religiosity with adolescent premarital sexual behavior in Serba Bakti high school and Madrasah Aliyah Serba Bakti Tasikmalaya. Farmer (2008) shows that among girls who have good religiosity, teenage girls who have had sexual intercourse was $0.67 \%$, while the rate was $2.9 \%$ worse religiosity. This shows that women's sexual behavior is influenced by religiosity. The purpose of this study is knowing the correlation between adolescent religiosity on sexual behavior in Senior High School in Bogor Barat. his study is a follow-up study of a 2013 study with a population of studies to obtain accurate data. The method used in this study is the analytical method with the cross-sectional approach. The data used is primary data obtained from the questionnaires taken from Senior High School in Bogor Barat. Research results in 2013 showed that five variables that were confonder were knowledge, attitude, organization participation, dating status and influence of friends. The interaction of that factors give influence for the adolescent sexual behaviour. Whereas in 2019 the results of the study showed that the four variables that were the confonder were attitude, parental influence, gender, friend influence.
\end{abstract}

Keywords - Religiosity, attitude, sexual behavior

\section{INTRODUCTION}

This template, modified in MS Word 2007 and saved as a "Several studies on sexual behavior reveal the number where sexual intercourse was first performed at a young age, around high school age or at the beginning of the lecture with an age range of 16 to 18 years $^{1}$.

According to the World Health Organization (WHO) adolescents have had greater sexual relations in $12^{\text {th }}$ grade students than $9^{\text {th }}$ grade students, respectively $49.5 \%$ and $19.8 \%$. According to the study, McCabe and Collins discuss how sexy desires and behavior of Australian teenagers aged 16-17 years, such a clear desire to increase the sexy intimacy of the first date dating. $88 \%$ of boys and $29 \%$ of girls had breast petting, $41 \%$ of boys and $6 \%$ of girls had female genital stimulation on their first date ${ }^{3}$. The adolescent age category is the age category that is most vulnerable to various negative behaviors, such as risky sexual behavior. Risk sexual behavior is defined as sexual behavior that threatens health due to the exposure of various diseases that can be transmitted through sexual contact such as hepatitis $\mathrm{C}$, hepatitis $\mathrm{B}$, Human Immunodeficiency (HIV) and various other sexually transmitted infections ${ }^{4}$.

In Indonesia, Survei Kesehatan Remaja Republik Indonesia (SKRRI) 2012 get $29.5 \%$ of teenage boys and $6.2 \%$ of teenage girls have touched or stimulated their partners, $48.1 \%$ of teenage boys and $29.3 \%$ of teenage girls have kissed lips, and $79.6 \%$ of teenage boys and $71.6 \%$ of adolescent girls have held hands with their partners ${ }^{5}$.

Based on the results of Ariyandini's research in 2012, it was found that $10.2 \%$ of general high school students agreed about premarital sex. On the other hand $22.2 \%$ of religionbased high school students agreed about premarital sex. This shows that there is no difference in attitudes between high school students and religious-based high school students, because the level of religiosity is not only influenced by education in schools, but is also influenced by education provided by parents, the environment and others ${ }^{6}$.

There are two important things that underlie sexual behavior in adolescents, namely the hope to get married in a relatively small age (age 20 years) and the increasingly rapid flow of information that can cause sexual arousal in adolescents, especially adolescents in urban areas. These stimuli encourage teens to have premarital sexual relations ${ }^{7}$.

Other factors that influence adolescent sexual behavior are puberty, sex, parental supervision, level of knowledge about reproductive health and attitudes towards various sexual behaviors $^{8}$

\section{METHOD}

This study is a follow-up study of a 2013 study with a population of studies to obtain accurate data. This research used analytical method with cross sectional approach. Population of this study were all of the $2^{\text {nd }}$ grade students of SMAN 5 Bogor with the amount of the students is 348 people. This research used the Proportionate Random Sampling Technique because the population consists of 9 classes (6 science classes and 3 social studies classes). In the calculation of the size of the sample using the Solvin Technique, counted 186.09,integratongg the sample to 186 respondents. Research location is a place for research activities, that located in SMA Negeri 5 Kota Bogor. This research started from data collecting and ended with processing the result of the research. Time of the research is July 2013. Data used in this research is 
primary data with the research instrument is questionnaire tested in validity and reliability of each question.

In 2019 the study added the research site to a high school / vocational high school in Bogor Barat district. The study population was all students in the SMA / SMK West Bogor District area with a total population of 1441 students / i. The sample in this study used a total sampling technique using inclusion and exclusion criteria.

\section{RESULTS AND DISCUSSION}

The results of further analysis found several variables that have a $p$ value of less than 0.05 ( $p$ value $<0.05$ ). The results of multivariate analysis that have been carried out through all stages obtained final modeling from the analysis as follows:

TABLE I. Multivariate Final Modeling Results IN 2013

\begin{tabular}{|c|c|c|c|c|c|}
\hline Variable & B & SE & Wald & $\begin{array}{c}\text { P } \\
\text { Value }\end{array}$ & $\begin{array}{c}\text { OR } \\
(95 \%)\end{array}$ \\
\hline Religiousness & 4.685 & 1.307 & 12.843 & $\mathbf{0 . 0 0 0}$ & $\mathbf{4 8 . 2 6 3}$ \\
\hline Attitude & 5.923 & 1.656 & 12.794 & $\mathbf{0 . 0 0 0}$ & $\mathbf{3 7 . 6 3 2}$ \\
\hline Knowledge & $\mathbf{6 . 4 0 5}$ & 1.647 & 15.128 & $\mathbf{0 . 0 0 0}$ & $\mathbf{6 4 . 7 0 6}$ \\
\hline $\begin{array}{c}\text { Participation in } \\
\text { Organization }\end{array}$ & $\mathbf{5 . 3 1 3}$ & 1.607 & 10.934 & $\mathbf{0 . 0 0 1}$ & $\mathbf{2 2 . 9 0 3}$ \\
\hline Dating Status & $\mathbf{5 . 0 2 1}$ & 1.630 & $\mathbf{9 . 4 8 5}$ & $\mathbf{0 . 0 0 2}$ & $\mathbf{1 5 . 5 4 4}$ \\
\hline $\begin{array}{c}\text { Friends } \\
\text { Influence }\end{array}$ & $\mathbf{3 . 8 2 8}$ & 1.356 & $\mathbf{7 . 9 6 4}$ & $\mathbf{0 . 0 0 5}$ & $\mathbf{4 5 . 9 5 8}$ \\
\hline Constant & $\mathbf{4 . 6 8 5}$ & 1.307 & 12.843 & $\mathbf{0 . 0 0 0}$ & $\mathbf{4 8 . 2 6 3}$ \\
\hline
\end{tabular}

There are six variables included in the final modeling stage, namely the level of religiosity, attitudes, knowledge, organizational participation, dating status and peer influence.

According to Green theory, behavior is determined or formed from 3 factors, namely predisposing factors, enabling factors and reinforcing factors?

Based on the results of the analysis, it can be seen that the variable as the most related confounder is knowledge. The results of this study are consistent with Lisnawati's research that there is a relationship between the level of adolescent knowledge about reproductive health with adolescent sexual behavior $(\mathrm{P} \text { value } 0.009)^{10}$.

TABLE II. Multivariate Final Modeling RESUlts IN 2019

\begin{tabular}{|c|c|c|c|c|c|}
\hline Variable & B & SE & Wald & $\begin{array}{c}\text { p } \\
\text { Value }\end{array}$ & $\begin{array}{c}\text { OR } \\
(95 \%)\end{array}$ \\
\hline Religiousness & $\mathbf{0 . 3 9 9}$ & $\mathbf{0 . 1 3 6}$ & $\mathbf{8 . 6 5 1}$ & $\mathbf{0 . 0 0 3}$ & 1.490 \\
\hline Attitude & $\mathbf{0 . 5 5 5}$ & $\mathbf{0 . 1 5 2}$ & 13.328 & $\mathbf{0 . 0 0 0}$ & 1.741 \\
\hline $\begin{array}{c}\text { Parental } \\
\text { Influence }\end{array}$ & $\mathbf{0 . 4 4 2}$ & $\mathbf{0 . 1 3 8}$ & 10.329 & $\mathbf{0 . 0 0 1}$ & 1.556 \\
\hline Gender & $\mathbf{0 . 5 5 5}$ & $\mathbf{0 . 1 4 5}$ & 14.644 & $\mathbf{0 . 0 0 0}$ & 1.742 \\
\hline $\begin{array}{c}\text { Friends } \\
\text { Influence }\end{array}$ & $\mathbf{0 . 4 4 6}$ & $\mathbf{0 . 1 4 4}$ & $\mathbf{9 . 5 4 1}$ & $\mathbf{0 . 0 0 2}$ & 1.562 \\
\hline Constant & 1.277 & $\mathbf{0 . 2 9 7}$ & 18.473 & $\mathbf{0 . 0 0 0}$ & $\mathbf{3 . 5 8 5}$ \\
\hline
\end{tabular}

There are variables that include the final modeling, namely the level of religiosity, attitudes, parental influence, gender and peer influence.

As a transitional period from childhood to adulthood, adolescence is the beginning of physical, mental and social developments that will affect functioning in adulthood ${ }^{11}$. This period is full of changes and challenges, also development and opportunities ${ }^{12}$. Adolescents are particularly exposed to highrisk behaviors, and many of such behaviors are founded in this period, which will affect their future health and wellbeing. ${ }^{13}$ Because of selfishness and lack of proper understanding of consequences, adolescence is considered an important stage to start high-risk behaviors. ${ }^{14}$ High-risk behaviors can have detrimental effects on adolescents' development and health, or can impede their future success and development. ${ }^{15}$

The results of this study are in line with the research Lee YM, et, showed that five influential factors were identified: family-centered cultural values, parental relationship, acculturation, gender roles, and lack of knowledge and information about sex and STIs ${ }^{16}$.

Based on other research factors contributing to high-risk sexual behaviors in girls can be divided into four general groups including personal, family, peer, school, and community ${ }^{17}$.

\section{CONCLUSIONS AND SUGGESTIONS}

Research results in 2013 showed that five variables that were confonder were knowledge, attitude, organization participation, dating status and influence of friends. The interaction of that factors give influence for the adolescent sexual behaviour. Whereas in 2019 the results of the study showed that the four variables that were the confonder were attitude, parental influence, gender, friend influence.

The holding of the Community Development Program to develop the implementation of adolescent activities at the Puskesmas level in the form of Youth Care Health Services (PKPR) is considered to be good. PKPR can also be implemented through empowering peer educators and peer counselors for youth and school religious organizations such as health education on sexual and reproductive health, as well as other counseling with approaches to religious norms.

\section{ACKNOWLEDGMENT}

This research supported by Akademi Kebidanan Prima Husada Bogor.

\section{REFERENCES}

[1] Rahardjo, W. (2015). Peran harga diri dan perilaku seksual daring terhadap usia hubungan seks pertama kali dan jumlah pasangan seks pada pria heteroseksual lajang. Makalah. Dipresentasikan pada Seminar Nasional "Selamatkan Generasi Bangsa dengan Membentuk Karakter Berbasis Kearifan Lokal”. Fakultas Psikologi Universitas Muhammadiyah Surakarta,Juni 2015.

[2] World Health Organization, The United Nations Population Fund, and United Nations Educational, Scientific, and Cultural. Investing in our future: a framework for accelerating action for the sexual and reproductive health of young people. Geneva: WHO Press. 2006.

[3] Moore, S Et Al. Sexuality InAdolecents Current Trends London New York: Routledge. 2007.

[4] Centers for Disease Control and Prevention (CDC). Sexual Risk Behaviors: HIV, STD, \& Teen Pregnancy Prevention. http://www.cdc.gov/Healthy Youth/sexual behaviors. 2015.

[5] Badan Koordinasi Keluarga Berencana Nasional. Kondisi remaja mengkhawatirkan. Jakarta: http://www.bkkbn.go.id. 2014.

[6] Ariyandini, F. Perbedaan Tingkat Religiusitas Dan Sikap Terhadap SeksPranikah Antara Pelajar SMA Berbasis Umum Dengan Pelajar SMA Berbasis Agama. Surabaya. Jurnal Ilmiah Mahasiswa Univesitas Surabaya. 2012

[7] Manuaba IBG, Manuaba IAC, Manuaba IBGF. Pengantar kuliah obstetri. Jakarta: EGC; 2007.

[8] Nursal DGA. Faktor-faktor yang berhubungan dengan perilaku seksual murid SMU negeri di Kota Padang tahun 2007 (skripsi). Padang: Fakultas Kesehatan Masyarakat Universitas Andalas. 2008.

[9] Notoatmodjo, S. Promosi Kesehatan dan Ilmu Perilaku. Jakarta: Rineka Cipta. 2007.

[10] Lisnawati, Lestari. Faktor-Faktor Yang Berhubungan Dengan Perilaku Seksual Remaja di Cirebon. Jurnal CARE, Vol. 3, No. 1, 2015.

[11] Shahhosseini Z, Simbar M, Ramezankhani A. Female Adolescents Health-Information Needs: A Qualitative Study. J Mazand Univ Med Sci. 2011;21:82-5. [In Persian] 
[12] Maria Rosario deGuzman, Bosch K. High-Risk Behaviors in Youth USA: University of Nebraska; 2014. Available from:[http://extensionpublications.unl.edu/assets/pdf/g1715.pdf . ]

[13] Jackson CA, Henderson M, Frank JW, Haw SJ. An overview of prevention of multiple risk behaviour in adolescence and young adulthood. Journal of Public Health. 2012;34:31-40.

[14] Kloep M, Güney N, Cok F, Simsek OF. Motives for risk-taking in adolescence: A cross-cultural study. Journal of Adolescence. 2009;32:135-51

[15] DiClemente RJ, Hansen WB, Ponton LE. Handbook of adolescent health risk behavior. New York: Springer Science \& Business Media; 2013.
[16] Lee YM, Florez E, Tariman J, McCarter S, Riesche L. Factors related to sexual behaviors and sexual education programs for Asian-American adolescents. Appl Nurs Res. 2015 Aug;28(3):222-8. doi: 10.1016/j.apnr.2015.04.015. Epub 2015 May 29. Available from [https://www.ncbi.nlm.nih.gov/pubmed/26094879]

[17] Zainab Alimoradi, $\mathrm{PhD}$ candidate, Nourossadat Kariman, PhD, Masoumeh Simbar, PhD, and Fazlollah Ahmadi, PhD. Contributing Factors to High-Risk Sexual Behaviors among Iranian Adolescent Girls: A Systematic Review. Int J Community Based Nurs Midwifery. 2017 Jan; 5(1): 2-12. Available From [https://www.ncbi.nlm.nih.gov/pmc/articles/PMC5219561/] 